\title{
非冗長マニピュレータにおける逆キネマティクスの高速数值解法の提案
}

\author{
学生員高 橋 太郎 (横浜国立大学) 正員河 村 篤 男 (横浜国立大学)
}

High speed numerical solution to inverse kinematics for non-redundant manipulators

Taro Takahashi, Student-member, Atsuo Kawamura, Member (Yokohama National University)

キーワード：マニピュレータ、逆キネマティクス、オンライン制御

1.はじめに

先端座標の指令值から関節角度の指令值を求める逆キネ マティクスの解法として、ニュートンラプソン法が知られて いる。この手法では次数が高いと計算量が多くなりオンラ イン制御に用いることが難しいので、オフラインで計算さ れることが多い。また、例えば人間型ロボットが危険を感 知し、可能な限り高速に動きたい時などのように、その計 算機の能力内で可能な限り高速に指令值を求める必要のあ る場合もある。

このような状況をふまえて、ニュートンラプソン法にお いてヤコビ行列のある成分を0に置き換えることによって、 演算量を減らすことができる新しい解法を提案する。(1)

\section{2. 提案する手法}

関節角速度 $\dot{\theta}$ と先端速度 $\dot{x} の$ 関係は、次の式 (1)によって 表され、このヤコビ行列Jを用いて、先端の目標位置座標 を $x_{\text {ref }}$ を実現する関節角度 $\theta$ は、式 (2)のニュートンラプソ ン法の繰り返し演算により求めることができる。(2)(3)

$$
\begin{aligned}
\dot{\boldsymbol{x}} & =\boldsymbol{J} \dot{\boldsymbol{\theta}} \ldots \ldots \ldots \ldots \\
\boldsymbol{\theta}_{i+1} & =\boldsymbol{\theta}_{i}+\boldsymbol{J}^{-1}\left(\boldsymbol{x}_{\text {ref }}-\boldsymbol{x}_{\boldsymbol{i}}\right)
\end{aligned}
$$

ここで、提案する手法ではヤコビ行列 $\boldsymbol{J} の$ 代わりに、J の成分を一部 0 に置を換えた变形ヤコビ行列 $\boldsymbol{J}_{\text {mod }}$ を用い て、ニュートンラプソン法と同様の方法で解を求める。こ の $\boldsymbol{J}_{\text {mod }}$ は、ニュートンラプソン法の演算に拈いて必要にな る逆行列 $J_{\text {mod }}{ }^{-1}$ が少ない演算量で求まるように、各行各 列に扔いて一つの成分のみ残し，それ以外の成分を全て 0 に 置き換えた行列を用いる。このような行列を用いることに よって、もとの逆行列 $\boldsymbol{J}^{-1}$ と $\boldsymbol{J}_{\text {mod }}{ }^{-1}$ には多少の誤差を生じ るが、逆行列が非常に簡単に求められ演算量が大幅に少な くなる。そこで、 $J_{\text {mod }}{ }^{-1}$ の誤差について考える。 $J_{\text {mod }}$ 用いて現在の関節角速度から求めた先端速度 $\dot{x}_{\text {mod }}$ と、本来 のを用いて求めた先端速度 $\boldsymbol{x}$ との誤差べクトルをとと置 くと次式が導かれる。

$$
\begin{aligned}
\varepsilon & =\dot{\boldsymbol{x}}_{\text {mod }}-\dot{\boldsymbol{x}} \\
& =\left(\boldsymbol{J}_{\text {mod }}-\boldsymbol{J}\right) \dot{\boldsymbol{\theta}}
\end{aligned}
$$

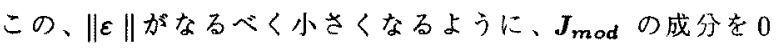
に置き換えるように工夫する。仮にJの沙成分をそのまま

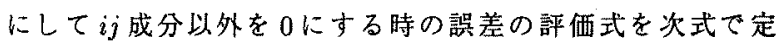
義する。

$$
\Delta\|\varepsilon\|_{i j}{ }^{2} \triangleq\left(\sum_{k=1, k \neq j}^{n} j_{i k} \dot{\theta}_{k}\right)^{2}-\left(\sum_{k=1}^{n} j_{i k} \dot{\theta}_{k}\right)^{2}
$$

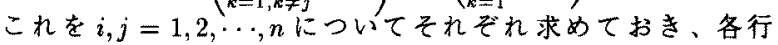
各列 1 成分のみ残すという条件のもとで $\min _{i, j}\left\{\Delta\|\varepsilon\|_{i j}\right\}$ を 満たす成分から優先して残すという作業を行なう。実際の 計算量については、同じ項が何回か出てくるのでその分は まとめて計算することにより十分少なくなる。

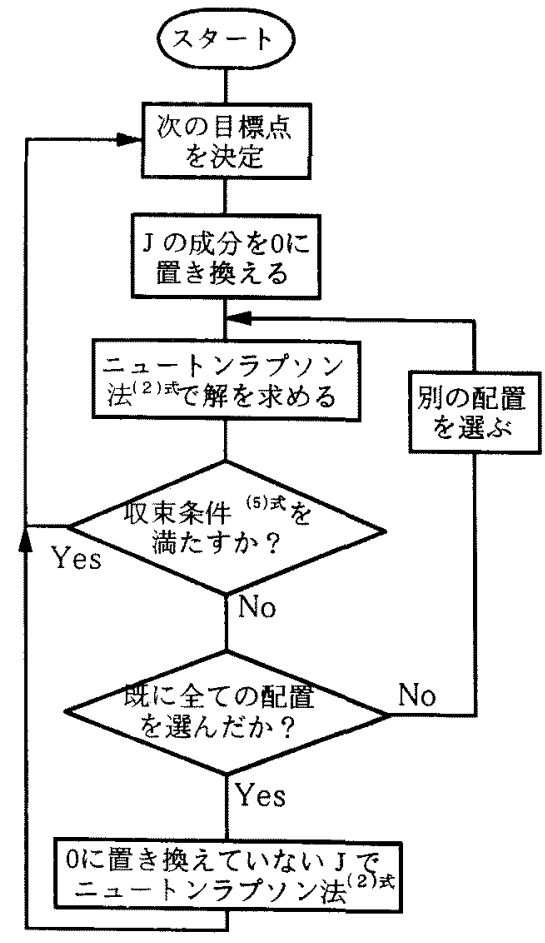

図 1 提案する手法

Fig. 1. The new method

T. IEE Japan, Vol. 118-D, No. 12, '98 
ところで、実際には $\Delta\|\varepsilon\|_{i j}$ の小さい成分加ら置き換えて も収束する解が求まらない場合があり得る。そのため、図 1のアルコリズムのように収束しない場合は組合せを变更 していく。まず、優先順位の低かった（最後に置き換えた） 成分をもとに戻し、各行各列 1 成分の及残すという条件の 中で別の成分を選ぶ。さらに収束しない場合は、同様に順 次優先順位の低い成分から変更していく。なお、収束して いるかしていないかは、十分小さな正の值入を用いた次の 条件式で判別するものとする。

$$
\left\|x_{r e f}-x_{i}\right\| \leq \lambda
$$

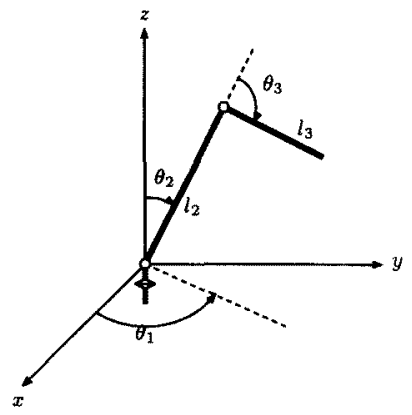

図 23 軸マニピュレータ

Fig. 2. Manipulator with 3 D.O.F.s

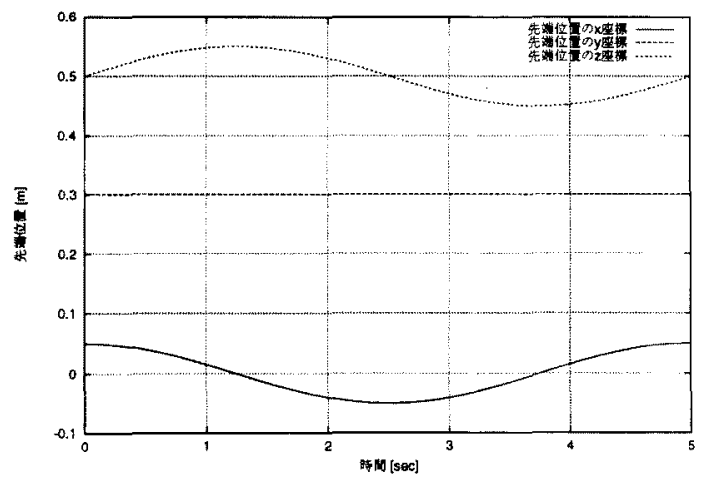

図 3 計算䑩果

Fig. 3. The result of calculation

\section{3. 計算例}

マニピュレータとして図 2 のような $l_{2}=0.4[\mathrm{~m}], l_{3}=0.3[\mathrm{~m}]$ の 3 軸マニピュレータを想定し、目標軌道 $x_{\text {ref }}$ は平面 $\mathbf{y}=$ $0.3[\mathrm{~m}]$ 上に半径 $0.05[\mathrm{~m}]$ 、中心 $(x, y, z)=(0.0,0.3,0.5)$ の円描く ように設定した。このとき、スタートは $(x, y, z)=(0.05,0.30,0.5)$ として $y$ 軸正の方向から見て、時計回りに5[sec]で 1 周させ た。この際、ニュートンラプソン法の刻み幅は $h=0.01$ [sec] とし、 $\lambda=0.001[\mathrm{~m}] 、$ 繰り返し回数は各時刻で 1 回とした。 图1に従って求めたJ ン法の演算を行なった結果を図 3 に示す。これを見ると、発 散せずに目標軌道を実現する関節角度が求まっていること が分かる。

\section{4. 計算コストの比較}

表 1 に通常の Gauss-Jordan 法を用いて連立一次方程式の 解を求めた場合と、提案する手法で求めた場合の計算コス 卜を、ヤコビ行列が $n$ 行 $n$ 列の場合について示す。今回の計 算例で用いた 3 軸マニピュレー夕の場合では $n=3$ となる。

なお、収束する組合せが見つかる回数によって計算回数は 異なる。そこで、全ての姿勢について計算を試み、収束する 組合せが選ばれる確率を求めた。設定した姿势は関節角度

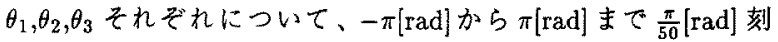
みで $100^{3}$ 通りの姿势を設定した。またそれらの姿警のそれ ぞれについて、目標軌道として $x y z$ の各軸の正、及び負の方 向に直線軌道を設定し、速度 $0.01[\mathrm{~m} / \mathrm{sec}]$ で $0.1[\mathrm{sec}]$ 動かした。 なお、刻み幅は $h=0.01[\mathrm{sec}] 、 \lambda=0.001[\mathrm{~m}]$ 、繰り返し回数は 1 回とし、特異点を除外するために可操作度 $\operatorname{det} J \geq 10^{-10}$ の姿勢に限定した。

これらの確率から計算コストの期待值を求め表 1 に示し た。提案する手法のほうが計算コストの面で有利であり、 演算量は $n$ が大きくなると $\frac{1}{100}$ 程度になることが分かる。

なお、J 拉で 0 に置き換えるべき成分はマニピュレータ の姿势に依存しているので通常の速度で動く場合には連続 した何回かは同じ成分を選択するだでよい。よって、こ れらの演算回数をさらに減らすこともできる。

\begin{tabular}{|c|c|c|c|}
\hline & +- & $x$ & $\div$ \\
\hline Gauss- Jordan 法 & $\frac{n(n-1)(n+1)}{2}$ & $\frac{n(n-1)(n+1)}{2}$ & $\frac{n(n+1)}{2}$ \\
\hline 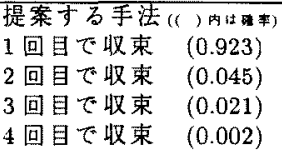 & $\begin{array}{l}3 n^{2}+n \\
3 n^{2}+3 n \\
3 n^{2}+5 n \\
3 n^{2}+7 n\end{array}$ & $\begin{array}{l}2 n^{2}+3 n+2 \\
2 n^{2}+4 n+4 \\
2 n^{2}+5 n+6 \\
2 n^{2}+6 n+8\end{array}$ & $\begin{array}{l}n+1 \\
2 n+2 \\
3 n+3 \\
4 n+4\end{array}$ \\
\hline $\begin{array}{l}\text { 収束せずニュートン } \\
\text { ラプソン法 } \quad(0.010)\end{array}$ & $\begin{array}{l}\frac{n(n-1)(n+1)}{2} \\
+3 n^{2}+7 n \\
\end{array}$ & $\begin{array}{l}\frac{n(n-1)(n+1)}{2} \\
+2 n^{2}+6 n+8 \\
\end{array}$ & $\begin{array}{l}\frac{n(n+1)}{2} \\
+4 n+4 \\
\end{array}$ \\
\hline $\begin{array}{l}\text { 提案する手法の } \\
\text { 演算回数の期待倠 }\end{array}$ & $\begin{array}{l}0.005 n^{3} \\
+3.00 n^{2}+1.24 n\end{array}$ & $\begin{array}{r}0.005 n^{3}+2.00 n^{2} \\
+3.12 n+2.25 \\
\end{array}$ & $\begin{array}{l}0.005 n^{2} \\
+1.13 n+1.12 \\
\end{array}$ \\
\hline
\end{tabular}

表 1 計算コストの比較(確率は $n=3 、 \lambda=0.001$ の場合)

Table 1. The calculation costs

5.まとめ

ニュートンラプソン法を行なうに当たって、ヤコビ行列の 一部を0に置き換えることにより、少ない演算量で解を求め

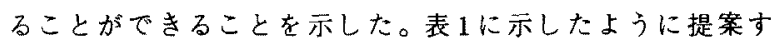
る手法がうまく機能しない場合の可能性は非常に低く、た とえその場合でも従来の手法で求まる。ただし、オンライ ン制御に用いる際には(1) 節約できた時間を他の計算に有 効利用するが、提案する手法がうまく機能しない場合を想 定してサンプル時間を決めて扔くか、または、(2)収束しな い場合は 1 サンプル前の関節角度を使うなどの工夫が必要 である。(平成 10 年 5 月 18 日受付、平成 10 年 8 月 10 日再受付)

\section{文献}

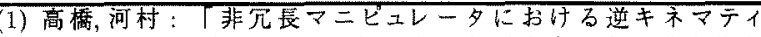
クスの高速数値解法」, 平成 10 年電気学会全国大会講演猃文 集,No.639

(2) 今野, 山下：「韭楾形計画法」，日科技連, 1978 .

(3) John J.Craig:「口ボティクス」, 共立出版株式会社,1991.

高橋太郎(学生貝) 1973 年 9 月 10 日生。現在、横浜国立大 学大学院工学研究科搏士課程前期在学中。

河村篤男(正員) 電学諭誌 D, 平成 9 年 117 巻 6 月号,P.732 参照 